\title{
Mycorrhizal Colonization Patterns Under Contrasting Grazing and Topographic Conditions in the Flooding Pampa (Argentina)
}

\author{
Gonzalo Grigera ${ }^{1}$ and Martin Oesterheld ${ }^{2}$
}

\author{
Authors are ${ }^{1}$ graduate student and ${ }^{2}$ associate professor, IFEVA, Departamento de Recursos Naturales, Facultad de Agronomia, \\ Universidad de Buenos Aires/Conicet. Av. San Martin 4453, C1417DSE Buenos Aires, Argentina.
}

\begin{abstract}
Arbuscular mycorrhizae (AM) can ameliorate the impact of disturbance on agroecosystem sustainability. The objective of this study was to describe mycorrhizal colonization patterns in contrasting grazing situations (exclosure and continuous grazing) and topographical positions (upland and lowland) in the flooding pampa (Argentina). We determined the mycorrhizal colonization of the community as a whole and of Dallis grass (Paspalum dilatatum Poir.), a highly palatable, dominant species. We characterized colonization by the proportion of root length occupied by fungi and their different structures. At the community level, there was higher total colonization in the grazed area than in the exclosure. In contrast, Dallis grass showed higher total colonization and higher proportion of vesicles and arbuscules in the exclosure than in the grazed area. For both levels, colonization was higher in the lowland than in the upland position. Differences were observed only in winter and spring, not in summer. Our results show that 1) continuous grazing is associated with an increase of mycorrhizal colonization at the community level and 2) community-level patterns of mycorrhizal colonization cannot be inferred from dominant species. To our knowledge, this is the first characterization of AM abundance at the plant community level under contrasting long-term grazing conditions in a subhumid grassland.
\end{abstract}

\section{Resimen}

Las micorrizas arbusculares pueden amortiguar el impacto de ciertos disturbios sobre la sustentabilidad de los agroecosistemas. El objetivo de este trabajo fue describir la colonización micorrícica bajo condiciones contrastantes de pastoreo (clausura y pastoreo continuo) y topografía (bajos y planos ligeramente más altos) en la Pampa Deprimida (Argentina). Determinamos la colonizaciœn micorrícica de la comunidad en conjunto y de pasto miel (Paspalum dilatatum Poir.), una especie dominante muy palatable. Caracterizamos la colonización como la proporción de la longitud radical ocupada por hongos micorrícicos y sus diferentes estructuras. A nivel de comunidad, la colonización total fue mayor en el área pastoreada que en la clausurada. En cambio, el pasto miel mostrœ mayor colonización total y proporción de vesículas y arbúsculos en el área clausurada. Para ambos niveles, la colonización fue mayor en la posición topografica baja que en la más alta. Las diferencias fueron encontradas en invierno y primavera, pero no en verano. Los resultados muestran que (1) el pastoreo continuo está asociado a un aumento de la colonizaciœn micorrícica de la comunidad, y (2) los patrones de colonización micorrícica a nivel de comunidad no pueden ser inferidos a partir de una especie dominante. Esta es la primera caracterización de la abundancia de micorrizas arbusculares en la comunidad vegetal en conjunto de pastizales subhúmedos sometidos por varios años a condiciones contrastantes de pastoreo.

Key Words: vesicular-arbuscular mycorrhizae, subhumid grassland, plant community, Dallis grass, belowground processes, species interactions

\section{Introduction}

The arbuscular mycorrhizal (AM) symbiosis is an association between fungi and plant roots: Carbon flows from plants to fungi, whereas soil mineral nutrients, especially phosphorus, flow from fungi to plants (Smith and Read 1997). Fungi extend into the soil and colonize the root cortex with various structures: Hyphae, which absorb and transport carbohydrates and nutrients; vesicles, which store lipids; and arbuscules, which are involved in nutrient transfer from fungi to plants (Smith and Read 1997). The degree of plant colonization

Research was funded by Universidad de Buenos Aires and Agencia Nacional de Promoción Cientíica y Tecnológica of Argentina (FONCyT, PICT99 06-06761).

Correspondence: Gonzalo Grigeria, IFEVA, Departamento de Recursos Naturales, Facultad de Agronomía, Universidad de Buenos Aires/Conicet. Av. San Martín 4453, C1417DSE Buenos Aires, Argentina. Email: ggrigeria@ifeva.edu.ar

Manuscript received 14 July 2003; manuscript accepted 14 April 2004. (colonization intensity) and the proportion of different fungal structures (colonization quality) depend on plant species and environmental factors (McNaughton and Oesterheld 1990, Koide and Schreiner 1992, Sanders and Fitter 1992).

Grazing may potentially affect AM colonization at two hierarchical levels: The individual plant and the community as a whole. At the individual plant level, a variety of responses have been documented: Under intense defoliation regimes, colonization intensity decreased (Bethlenfalvay and Dakessian 1984; Bethlenfalvay et al 1985; Hetrick et al 1990), whereas, under milder regimes, it was either unaffected or increased (Wallace 1981, 1987; Wallace and Svejcar 1987; Eom et al 2001). At the community level, there are no studies directly assessing grazing effect on colonization.

The objective of this study was to describe mycorrhizal colonization intensity and quality of the community as a whole and of Dallis grass (Paspalum dilatatum Poir.) under contrasting grazing and topographic conditions in the flooding pampa (Argentina). Mycorrhizal colonization of the community as 
a whole is, at the same time, a rangeland attribute and a biotic factor that contributes to regulation of its dynamics (Wallace 1981, 1987; McNaughton and Oesterheld 1990; Sanders and Fitter 1992). Because livestock grazing is the main use of rangelands, investigation of grazing effects on AM abundance should allow us to better predict and understand rangeland dynamics (Eom et al 2001). To our knowledge, this is the first characterization of AM abundance at the plant community level under contrasting long-term grazing situations in a subhumid grassland.

\section{Materials and Methods}

\section{Site Description}

The study was conducted in the flooding pampa, a large subregion at the center of the pampas in Argentina. Climate is temperate subhumid. Mean annual precipitation is $900 \mathrm{~mm}$ evenly distributed throughout the year $(60 \%$ in spring-summer period). Mean monthly temperature ranges from $6.8^{\circ} \mathrm{C}$ in JulyAugust to $21.8^{\circ} \mathrm{C}$ in January. About 20 frost events occur between May and September. Landscape-level heterogeneity consists of a mosaic of two extended topographical levels subjected to different flooding regimes: The upland position is less frequently and intensely flooded than the lowland position (Burkart et al 1990; Perelman et al 2001). Despite these differences, floods occur almost annually at both landscape levels. A minor proportion of the area is occupied by higher and lower topographical units than the two just described, and will not be considered in this study. Upland soils are natric, consisting of acidic, nonsaline A1 horizon and a saline, highly alkaline B2 horizon, whereas lowland soils are argilic, with an acidic upper layer and a deeper alkaline layer (Perelman et al 2001).

Species composition responds to local variations in topography, which are in turn associated with different soil salinity and alkalinity, but it has also been shaped by a century of livestock grazing. The upland is covered by humid mesophytic meadows (hereafter referred to as upland community), whereas the lowland is covered by humid prairies (hereafter referred to as lowland community) (Sala et al 1986; Burkart et al 1990; Perelman et al 2001). Exclosures are nearly exclusively composed of native tussock grasses, whereas grazed areas have lower abundance of those species and higher abundance of exotic species, mostly forbs (Sala et al 1986; Perelman et al 2001). Dallis grass is a native, highly palatable grass that behaves as dominant in both communities and under contrasting grazing regimes (Burkart et al 1990; Perelman et al 2001). Primary production is maximum in spring, but because of mild winter conditions, considerable photosynthetic activity is observed year-round (Sala et al 1981).

We worked at the "Las Chilcas" ranch (lat $36^{\circ} 30^{\prime}$ 'S, long $58^{\circ} 30^{\prime} \mathrm{W}$ ). We sampled 2 exclosures, which were 5 (at the upland community) and 29 (at the lowland community) years old, and the surrounding areas, which have been subjected to year-round grazing with a stocking density of $0.55 \mathrm{cow} \mathrm{ha}^{-1}$, the typical management of the flooding pampa grassland (Oesterheld et al 1998). Weather conditions during the study were as expected for an average year in this region, with both flooding and drought coinciding within the same year (Paruelo and Sala 1990). Particularly in winter and spring, the ground surface of both communities was covered by more than $5 \mathrm{~cm}$ of water, while in summer soil water content was low (Oyarzábal 2003, personal communication).

\section{Sample and Laboratory Procedures}

Sampling took place in winter, late July 2001; spring, late October 2001; and summer, late January 2002. For communitylevel sampling, at each date, 56 -cm-diameter $\times 10-\mathrm{cm}$-depth soil cores were randomly extracted from each combination of grazing and vegetation community. Several observations indicate that belowground biomass consists of an interspersed net of roots and rhizomes from different species, and, as a result, the cores properly sampled community-level roots rather than just one or a few species. These grasslands have high plant cover (nearly $100 \%$ ) and concentrate a high number of species within a small area (21 and 11 species $\mathrm{m}^{-2}$ under grazing and exclosure, respectively; Chaneton et al 2002). Additionally, about $70 \%-90 \%$ of the individuals intercepted by vegetation transects occupied less than $2 \mathrm{~cm}$, which indicates a very fine-grained community structure that may be correctly sampled with cores of the size we used (Sala et al 1986). At the same dates and locations, roots of each of 5 randomly selected individuals of Dallis grass were excavated to a depth similar to that of the soil cores $(10 \mathrm{~cm})$, and saved for further processing in the laboratory.

In the lab, roots were washed free of soil, cut in approximately $1-\mathrm{cm}$-length segments, and stained in trypan blue (Phillips and Hayman 1970). Mycorrhizal colonization quality (Smith and Read 1997) was established as the percentage of root length occupied by fungal hyphae, vesicles, and arbuscules, respectively. Total colonization intensity consisted of the sum of all these percentages. Colonization was estimated at 200 magnification according to the magnified intercept method (McGonigle et al 1990). In this technique, a microscope slide with root segments is examined along a predetermined trajectory. At each intersection between a microscope eyepiece crosshair and a root segment, the presence of hyphae, vesicles, arbuscules or the absence of colonization is registered. Results are expressed as percentage of total intersections examined. To avoid subjectivity related to the origin of the sample, a blind procedure was used throughout the quantification process.

\section{Statistical Analyses}

Analysis of variance was performed to evaluate the differences between grazing situations and communities. The experimental design was a $2 \times 2$ factorial with grazing (grazed area and exclosures) and community (upland and lowland) as factors. Colonization data from community and Dallis grass, at each sampling date, were analyzed independently. Since we did not have independent replicates of the grazing and community situations, we used the statistical analysis to evaluate differences between sites (Hurlbert 1984; Wester 1992). Assignment of those differences to grazing effects is a matter of judgment that, in this case, is supported by the low chance that the exclosures and the surrounding grazed areas differ in factors other than grazing. The exclosures were installed with the specific purpose of studying grazing effects; thus, special care was taken to build them in homogeneous areas that granted the 


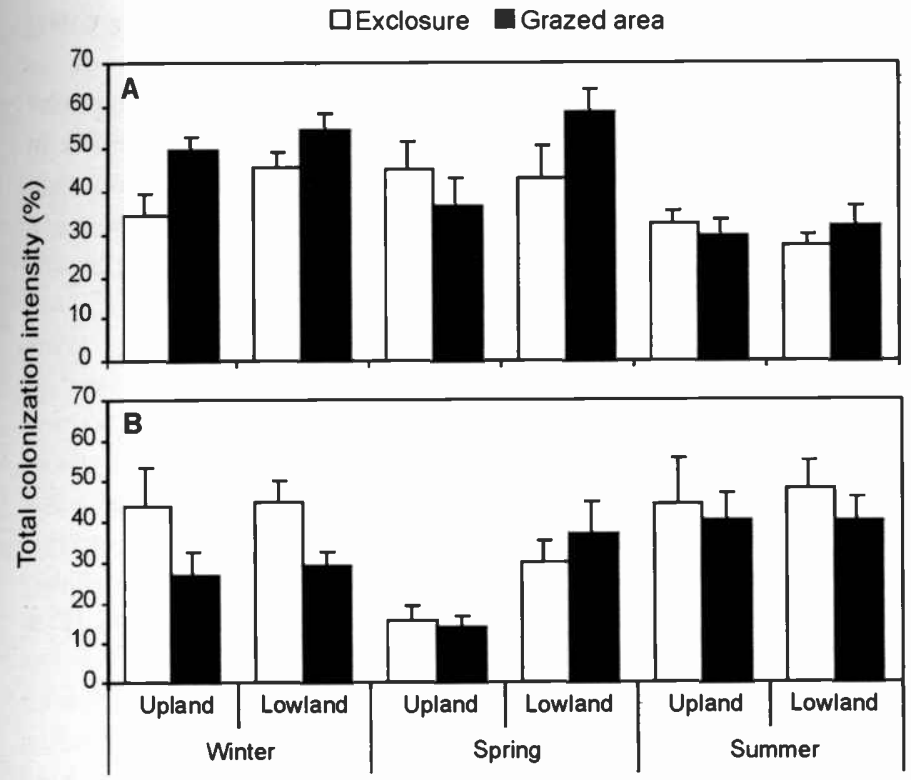

Figure 1. Total arbuscular mycorrhizae (AM) colonization intensity of community samples (A) and of Dallis grass (Paspalum dilatatum Poir.) (B) in 3 seasons and 2 plant communities subjected to contrasting grazing conditions in the flooding pampa. Vertical bars indicate 1 SE.

comparison between inside and outside (León and Oesterheld 2003, personal communication). Both the number of replicates per treatment (5) and the number of interceptions to be registered at microscope observation (110) were established from previous determinations especially designed to explore the variability of the parameters involved (Eckblad 1991). Before the statistical analysis, data were arcsine transformed, because of being proportions, but back-transformed values are presented (Jerrold 1999). Our conclusions are based on a $0.05 \alpha$ level, but we occasionally refer to results with slightly higher $\alpha$ level as worth noticing.

\section{Results}

\section{Mycorrhizal Colonization Intensity}

Mycorrhizal colonization intensity of the community as a whole varied between grazing and community situations, and some of these variations depended on the season (Fig. 1A). In winter, colonization intensity was $30 \%$ higher in the grazed situations than in the exclosures $(F=9.01, P<0.008)$, and $18 \%$ higher in the lowland than in the upland community $(F=3.69$, $P<0.07)$. In spring, the colonization pattern related to grazing was different in each community $(F=3.21, P$ interaction $<0.09$ ). In the upland community, total colonization was higher in the exclosure, whereas in the lowland community, it was higher in the grazed area. Finally, in summer, colonization did not differ between grazing or community situations (Fig. 1A).

Mycorrhizal colonization levels of Dallis grass also varied in a different manner depending on the time of the year (Fig. 1B). In winter, colonization intensity was $60 \%$ higher in the exclosures $(F=6.63, P<0.02)$, and there were no differences between communities $(F=0.05, P<0.81)$. Conversely, in spring, colonization intensity did not differ between the grazing

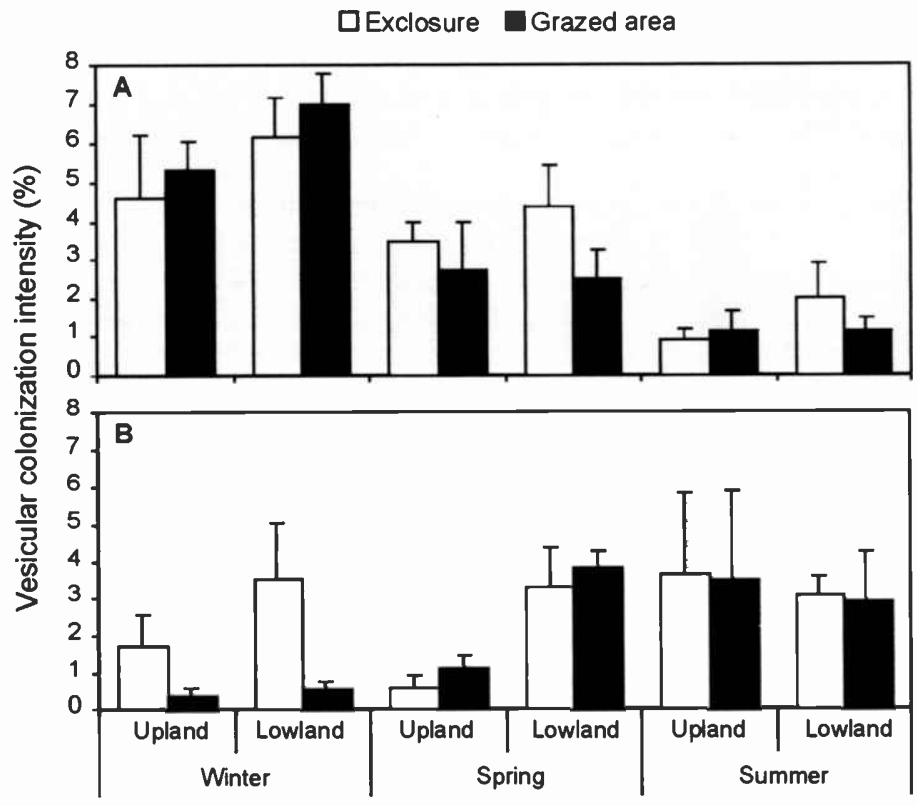

Figure 2. Vesicular colonization intensity of community samples (A) and of Dallis grass (Paspalum dilatatum Poir.) (B) in 3 seasons and 2 plant communities subjected to contrasting grazing conditions in the flooding pampa. Vertical bars indicate $1 \mathrm{SE}$.

situations $(F=0.18, P=0.67)$, and was $127 \%$ higher in the lowland than in the upland community $(F=14.18$, $P<0.002)$. Finally, in summer, colonization did not differ between grazing or community situations (Fig. 1B).

\section{Mycorrhizal Colonization Quality}

The relative contribution of each fungal structure to total colonization was independent of total colonization intensity. In all cases, hyphae represented more than $75 \%$ of total colonization, whereas vesicles and arbuscules never exceeded $14 \%$ and $21 \%$, respectively. Thus, variation in colonization with hyphae was closely correlated with those of total colonization described above $\left(r_{\text {hyphae }}\right.$ vs. total $\left.=0.97\right)$. On the contrary, colonization intensity with vesicles and arbuscules showed less correlation with total colonization intensity $\left(r_{\text {vesicles vs. total }}=0.68 ; r_{\text {arbuscules }}\right.$ vs. total $=0.32$ ). Thus, in the subsequent paragraphs we will only refer to vesicles and arbuscules to describe the responses in terms of colonization quality.

Vesicular colonization of the community samples did not significantly differ between grazing or community situations at any sampling dates (Fig. 2A). However, Dallis grass roots showed differences depending on season (Fig. 2B). In winter, vesicular colonization was 5 times higher in the exclosures than under grazed conditions $(F=4.45, P<0.05)$, but there were no differences between upland and lowland communities $(F=0.47, P=0.50)$. In spring, colonization did not differ between grazing situations $(F=1.94, P=0.18)$, but it was 3 times higher in the lowland than in the upland community $(F=21.3, P<0.0003)$. Finally, in summer, vesicular colonization did not differ between grazing or community situations (Fig. 2B).

Arbuscular colonization of the community samples only differed in winter (Fig. 3A). At this time, arbuscular colonization in the upland community was higher in the grazed area, 


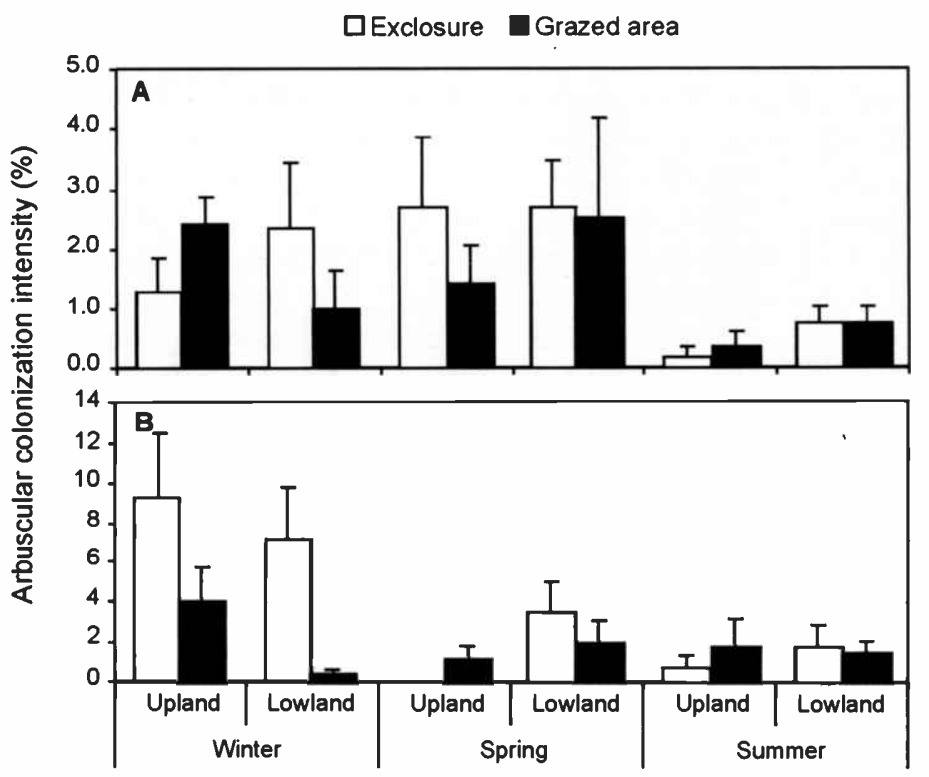

Figure 3. Arbuscular colonization intensity of community samples (A) and of Dallis grass (Paspalum dilatatum Poir.) (B) in 3 seasons and 2 plant communities subjected to contrasting grazing conditions in the flooding pampa. Vertical bars indicate $1 \mathrm{SE}$.

whereas in the lowland community it was higher in the exclosure $(F=3.14, P$ interaction $<0.09)$. Arbuscular colonization of Dallis grass in winter was 3 times higher in the exclosure than in the surrounding grazed area $(F=10.77$, $P<0.005$, Fig. 3B) and 2 times higher in the upland than in the lowland community $(F=3.64, P<0.08)$. In spring, arbuscular colonization did not differ between grazing situations $(F=0.2, P=0.66)$, and it was 4 times higher in the lowland than in the upland community $(F=5.4, P<0.03)$. Finally, in summer, arbuscular colonization did not differ between grazing or community situations (Fig. 3B).

\section{Discussion}

\section{Patterns of Colonization Intensity}

The association between colonization intensity and grazing differed between the two levels. At the individual plant level, colonization variations are usually explained by the cost:benefit ratio experienced by the host plant (Bethlenfalvay and Dakessian 1984; Koide and Schreiner 1992; Sanders and Fitter 1992). The higher colonization intensity of Dallis grass in the exclosure in winter supports the widespread concept that the less positive carbon balance induced by defoliation reduces colonization intensity (Bethlenfalvay and Dakessian 1984; Bethlenfalvay et al 1985; Hetrick et al 1990). At the community level, in general, when differences existed between grazing situations, colonization intensity was higher in the grazed areas than in the exclosures. Two nonexclusive mechanisms may explain these patterns. First, certain species might respond to grazing in an opposite manner to Dallis grass, because it has been shown that grazing effects on mycorrhizal colonization are species dependent (Wallace 1981; Bethlenfalvay et al 1985). Second, changes in botanical composition induced by grazing (Sala et al 1986) could increase the proportion of species with greater tendency to mycorrhizal colonization (Wallace 1981; Bethlenfalvay et al 1985).

Colonization intensity varied in association with topography in the same direction for both levels: When differences in colonization intensity existed between communities, colonization in the lowland was higher than in the upland community. Since the lowland community is more intensely and frequently flooded than the upland community (Perelman et al 2001), our result contrasts with observations in the Serengeti, where mycorrhizal colonization was reduced by intense flooding (Wallace 1981). The pattern observed, however, may be a result of differences in botanical composition between communities (Burkart et al 1990) and of environmental differences other than flooding, such as the higher soil salinity of the upland community (Perelman et al 2001). In fact, soil salinity negatively affects mycorrhizal symbiosis development (Kim and Webber 1985; Bethlenfalvay 1992).

An interesting feature of our results was that both winter and spring observations coincided with long-lasting flooding events, but nevertheless colonization intensity remained at high levels. Flooding and anaerobiosis in general have been thought to constrain the symbiosis (Smith and Read 1997). Flooding in winter and spring is frequent in the region (Paruelo and Sala 1990), and many species are considered flood-tolerant because they persist-and even increase biomass production-under flooding. For instance, Dallis grass retains root function by developing aerenchymatic tissue to avoid anoxia under flooding (Rubio et al 1995; Vasellati et al 2001). This trait is likely a source of oxygen to mycorrhizas, as it has been shown that aerenchymatic tissue helps maintain aerobic conditions in the rhizosphere (Howes and Teal 1994). High colonization under flooding is also surprising because this stress also decreases carbon allocation to roots and increases soil phosphorous availability (Rubio et al. 1997), two factors that usually decrease colonization.

\section{Patterns of Colonization Quality}

The association between colonization quality and grazing situations differed between the two levels we studied. Colonization quality of the community as a whole was less variable between sites than colonization intensity. It only varied in winter, when arbuscular colonization was higher under grazing in the upland community while it was higher in the exclosure in the lowland community. This decrease of arbuscular colonization in the lowland community contrasts with the increase observed in terms of total colonization intensity. Colonization quality of Dallis grass, however, varied in consonance with variations of total colonization intensity, but with higher relative magnitude. For instance, total colonization intensity in winter was $60 \%$ lower under grazing, whereas reductions in colonization were near $500 \%$ for vesicles and $300 \%$ for arbuscules. These results, if further studies show that they are extrapolable to a variety of situations, would indicate that grazing and topography affected not only the amount of colonization, but also its function.

\section{Management and Research Implications}

The relatively novel nature of livestock grazing as a disturbance in the flooding pampa region poses a threat to its sustainability 
(Sala et al 1986). Since AM have been singled out as indicators of agroecosystem sustainability (Bethlenfalvay 1992), our results provide the first evaluation of grazing impact on that indicator. Our results show that grazing, as compared to ungrazed situations, is associated with either no changes or increases of mycorrhizal colonization levels of plant communities. A similar response was observed in a dominant species of the U.S. tallgrass prairie (Eom et al 2001). Although the lack of reduction of AM colonization under grazing at the community level is reassuring, some of the patterns observed in Dallis grass may be a source of concern. Animal selectivity on this highly palatable forage species could determine higher grazing pressure compared with plant community on average. This fact not only contributes to explain the controversial result of mycorrhizal colonization intensity at the two levels, but also stresses the possibility that the mineral nutrition of palatable species is indirectly hindered by grazing through its effect on AM colonization.

Grassland ecosystem researchers agree on the need for more knowledge of mycorrhizal colonization patterns under field conditions (Bethlenfalvay et al 1985; Fitter 1985; Wallace 1987; Read 1991; Eom et al 2001). This is a consequence of numerous controversies between many glasshouse experiments and a few field-based experiments and observations (Bethlenfalvay 1992). To our knowledge, this is the first characterization of AM abundance at plant community level under contrasting long-term grazing conditions in a subhumid grassland. Our comparison of field patterns at two levels, the community as a whole and one of its dominant species, indicates that extrapolation of results from few species to communities may lead to wrong results.

\section{Acknowledgments}

We thank Marta Cabello, Gustavo Marino, and Mariano Oyarzábal for their assistance, and the owners and personnel of "Las Chilcas" ranch for facilitating our work there. Three anonymous reviewers made helpful comments on an earlier version of the manuscript.

\section{Literature Cited}

Betrlenfalvay, G. J. 1992. Mycorrhizae and crop productivity. In: G. J. Bethlenfalvay and R.G. Linderman [eds.]. Mycorrhizae in sustainable agriculture. Madison, WI: ASA special publication No. 54. p 1-27.

Bethlenfalvay, G. J., and S. Dakessian. 1984. Grazing effects on mycorrhizal colonization and floristic composition of the vegetation on a semiarid range in Northern Nevada. Journal of Range Management 37:312-316.

Bethlenfalvay, G. J., R. A. Evans, and A. L. Lesperance. 1985. Mycorrhizal colonization of crested wheatgrass as influenced by grazing. Agronomy Journal 77:233-236.

Burkart, S. E., R. J. C. León, and C. P. Movia. 1990. Inventario fitosociológico del pastizal de la Depresión del Salado (prov. Bs. As.) en un área representativa de sus principales ambientes. Darwiniana 30:27-69.

Chaneton, E. J., S. B. Perelman, M. Omacini, and R. J. C. León. 2002. Grazing, environmental heterogeneity, and alien plant invasions in temperate Pampa grasslands. Biological Invasions 4:7-24.

ECKBLAD, J. W. 1991. How many samples should be taken? BioScience 41: 346-348.

EOM, A. H., G. W. T. WILSON, AND D. C. HaRTNETt. 2001. Effect of ungulate grazers on arbuscular mycorrhizal symbiosis and fungal community structure in tallgrass prairie. Mycologia 93:233-242.
FitTer, A. H. 1985. Functioning of vesicular-arbuscular mycorrhizas under field conditions. New Phytologist 99:257-265.

Hetrick, B. A. D., G. W. T. WILSON, And C. E. Owensby. 1990. Mycorrhizal influence on big bluestem rhizome regrowth and clipping tolerance. Journal of Range Management 43:286-290.

Howes, B. L., AND J. M. TeaL. 1994. Oxygen loss from Spartina alterniflora and its relationship to salt marsh oxygen balance. Oecologia 97:431-438.

Hurlbert, S. H. 1984. Pseudoreplication and the design of ecological field experiment. Ecology Monographs 54:187-211.

JerRoLd, H. Z. 1999. Biostatistical analysis. 4th ed. Upper Saddle River, NJ: Prentice Hall.

KIM, C., AND D. J. WebBer. 1985. Distribution of VA mycorrhiza on halophytes on inland salt playas. Plant and Soil 83:207-214.

KoIde, R. T., AND R. P. SChreiner. 1992. Regulation of vesicular-arbuscular mycorrhizal symbiosis. Annual Review of Plant Physiology and Plant Molecular Biology 43:557-581.

McGonigle, T. P., M. H. Miller, D. G. Evans, G. L. Fairchild, and J. A. Swan. 1990. A new method which gives an objective measure of colonization of roots by vesicular-arbuscular mycorrhizal fungi. New Phytologist 115:495-501.

McNaughton, S. J., And M. Oesterheld. 1990. Extramatrical mycorrhizal abundance and grass nutrition in a tropical grazing ecosystem, the Serengeti National Park, Tanzania. Oikos 59:92-96.

Oesterheld, M., C. Di Bella, And K. Herdiles. 1998. Relation between NOAA-AVHRR satellite data and stocking rate of rangelands. Ecological Applications 8:207212.

Paruelo, J. M., and O. E. Sala. 1990. Caracterización de las inundaciones en la Depresión del Salado (Buenos Aires, Argentina): dinámica de la capa freática. Turrialba 40:5-11.

Perelman, S. B., R. J. C. León, and M. Oesterheld. 2001. Cross-scale vegetation patterns of Flooding Pampa grasslands. Journal of Ecology 89:562-577.

PhillipS, J. M., and D. S. Hayman. 1970. Improved procedures for clearing roots and staining parasitic and vesicular-arbuscular mycorrhizal fungi for rapid assessment of infection. Transactions of the British Mycological Society 55:158-161.

READ, D. J. 1991. Mycorrhizas in ecosystems. Experientia 47:376-391.

Rubio, G., G. CASASOLA, and R. Lavado. 1995. Adaptations and biomass production of two grasses in response to waterlogging and soil nutrient enrichment. Oecologia 102:102-105.

Rubio, G., M. Oesterheld, C. R. Alvarez, and R. S. Lavado. 1997. Mechanisms for the increase in phosphorus uptake of waterlogged plants: Soil phosphorus availability, root morphology and uptake kinetics. Oecologia 112:150-155.

Sala, 0. E., V. A. Deregibus, T. Schlichter, and H. Alippe. 1981. Productivity dynamics of a native temperate grassland in Argentina. Journal of Range Management 34:48-51.

Sala, O. E., M. Oesterheld, R. J. C. León, and A. Soriano. 1986. Grazing effect upon plant community structure in subhumid grasslands of Argentina. Vegetatio 67:27-32.

Sanders, I. R., and H. Fitter. 1992. The ecology and functioning of vesiculararbuscular mycorrhizas in co-existing grassland species. I. Seasonal patterns of mycorrhizal occurrence and morphology. New Phytologist 120:517-524.

Smith, S. E., and D. J. Read. 1997. Micorrhizal symbiosis. 2nd ed. London, UK: Academic Press.

Vasellati, V., M. Oesterheld, D. Medan, and J. Loreti. 2001. Effects of flooding and drought on the anatomy of Paspalum dilatatum. Annals of Botany 88:355-360.

WALLACE, L. L. 1981. Growth, morphology and gas exchange of mycorrhizal and nonmycorrhizal Panicum coloratum $\mathrm{L}$., a $\mathrm{C}_{4}$ grass species, under different clipping and fertilization regimes. Oecologia 49:272-278.

WALLACE, L. L. 1987. Mycorrhizal in grasslands: interactions of ungulates, fungi and drought. New Phytologist 105:619-632.

WaLlaCE, L. L., AND T. SVEJCAR. 1987. Mycorrhizal and clipping effects on Andropogon gerardii photosynthesis. American Journal of Botany 74:1138-1142.

WESTER, D. B. 1992. Viewpoint: Replication, randomization, and statistics in range research. Journal of Range Management 45:285-290. 